\title{
EVALUATION AND COMPARISON OF THE INFLUENCE OF MICROWAVE AS A DISINFECTANT METHOD ON THE COLOUR STABILITY, MECHANICAL AND PHYSICAL PROPERTIES OF THERMOPLASTIC (BREFLEX) AND ACRYLIC RESINS DENTURE BASE MATERIAL
}

\author{
Iman M.S.Matar ${ }^{*}$ and Ahlam M. El-Sharkawy**
}

\begin{abstract}
Microwave radiation has been used for sterilization and disinfection of dental prosthesis which considered as an alternate method for chemical disinfectants.Aim: to evaluate the influence of microwave as a disinfection procedure on the colour ,the transverse strength and dimensional stability on the thermoplastic resin denture base and compare it with two types of conventional acrylic resin at different exposure times
\end{abstract}

Material and methods: 180 samples were made, 60 for each of the next tests (colour, transverse strength and dimensional stability). The samples of each test, were subdivided into three groups each group has 20 samples according to the denture base material used (Breflex thermoplastic resin, heat cure and self cure). Each test were divided into four groups, one control and the other groups according to the time of microwave disinfection that were utilized (5,10,15 minutes) at 650 watt. Colour, transverse strength and dimensional stability parameters were measured with and without disinfection. Data were analyzed with ANOVA and Post-hoc Tukey's tests with statistically significant at $\mathrm{p} \leq 0.05$.

Result: Microwave disinfection had no significant influence on the colour, the transverse strength beside the dimensional changes of all denture base materials at all the disinfection intervals, except it has a significant influence on the colour of heat cure for 15 minutes. Breflex showed a significantly increase in the flexural strength also, improvement in its fitness to the casts when compared with both heat and self cured resins after treated with microwave.

Conclusion: Microwave can be used safely for disinfection of all the denture base material except heat cure for 15 minutes. Breflex is the best due to it has no influence on its colour , increase the flexural strength, as well as dimensionally stable when compared with both heat and self cured acrylic resins

KEY WORD: Microwave, Breflex, thermoplastic, conventional acrylic resins

* Lecturer, Department of Prosthodontics, Faculty of Dentistry, Pharos University, Alexandria, Egypt

** Professor, Department of Prosthodontics, Faculty of Dentistry, Alexandria University, Egypt 


\section{INTRODUCTION}

Oral hygiene have considerable value specially with removable prosthodontics wearers, because they may be the possibility origin of infection due to the aggregation of deposits, such as food remnants, stains as well, it may cause unpleasant breath, periodontal diseases and caries in patients with remaining teeth. Dentures can be the position of the microorganisms that may cause systemic diseases as stomach, intestinal infections, pneumonia and bacterial endocarditis ${ }^{(1)}$.

In addition, they have the ability to adhere the tissue surface of dentures causing initiation and spread of denture stomatitis ${ }^{(2)}$.Which is the most prevalent form of oral candidal infection with total incidence of around $65 \%$ of denture wearers ${ }^{(3)}$. Treatment of denture stomatitis contains perfect oral hygiene, denture cleaning techniques, systemic or topical antifungal medication, Cessation of denture wear and finally, replacement of the denture $(3,4)$.

Cleaning the dentures should be easy and quick ,there are several techniques to disinfect denture, mechanical procedures as well as chemical procedures in addition cleanser tablets. ${ }^{(5)}$.

The disinfection techniques for complete and partial dentures are yet controversial because they can change some properties of the materials and

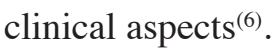

Therefore, other techniques, like microwave radiation oven has been introduced to be used in disinfection of dentures due to the simple approach in many houses and the problem of denture disinfection by most of the elderly patients ${ }^{(6,7)}$.

It is used as alternate to the domestic brushing in addition as an alternative to chemical disinfectants because it is more effective, free from chemicals, fast, there is no need for specific storage, it hasn't an expiry date and does not encourage resistance to Candida albicans as well as It destroy the growing microorganisms ${ }^{(8)}$.
Microwaves are a kind of electromagnetic energy with wavelengths nearby in frequency to television transmissions. It is known that heating in microwave is an energy transformation and differs in heating with conventional oven ${ }^{(9)}$.

The master goal of microwave disinfection is to disrupt potentially pathogenic microorganisms but the precise technique of microwaves for destruction of microorganisms not clearly understood ${ }^{(10)}$.

Several studies claiming that the destruction of the microorganisms is directly of thermal manner,while others claiming that non thermal manner has a significant action ${ }^{(7,10)}$.

The effectiveness of microwave radiation appear to be related with the strength of the microwave oven, exposure time, the medium in which the dentures are Submerged and the kind of microorganisms ${ }^{(11)}$.

A study evaluated the Influence of microwave as a disinfectant of the dentures which infected by $\mathrm{C}$. albicans. The test displayed that the dentures when Submerged in water path for 5 minutes in the microwave all microorganisms were removed ${ }^{(12)}$. Another Research claimed that the uses of microwave (650 W for 6 minutes) caused sterilization of the dentures from S.aureas and C.albicans ${ }^{(13)}$.

Microwave irradiation efficiency seems to be related with the kinds of denture base materials. Thus, establishing the protocol of microwave must be fundamental with the goal to obtain sterilization without damage the denture base materials ${ }^{(14)}$. Heat cure polymethyl methacrylate is The widely used material in complete dentures construction ${ }^{(15)}$.

Nowadays dentists are recommended flexible material for removable prosthodontics specially the cases having undercut areas which can be used for retention. Thermoplastic acrylic resin materials chosen in partial dentures cases because its flexibility allows it to avoid or minimize masticatory stresses from being transmitting to the tissues and adjacent teeth ${ }^{(16)}$.

The colour of denture bases of these materials 
are coincide with the oral mucosa in addition remove the use of metal clasps ${ }^{(17)}$.

Sinch et al. in $2013^{(18)}$ concluded that flexible partial dentures (FPD) could be the choice for the replacement of missing teeth when the patient is worried about aesthetics. FPD had given an alternative to the complicated designing of metallic partial dentures.

However, there is little knowledge concerning the influence of microwave irradiation on the colour stability, mechanical and physical properties of the thermoplastic resin materials.

As a result, this study performed to assess the influence of microwave as a disinfection procedure on the thermoplastic resin denture base and compare it with two types of conventional acrylic resin at different exposure times as regards the colour stability (aesthetics regarding the colour of denture base material is an essential factor for its success), the transverse strength (as an indicator of strength of denture bases)and dimensional stability (as it affect the retention and stability of the denture as well as keeping the supporting tissues healthy)in order to choose the best material for denture construction

\section{MATERIALS AND METHOD}

In this study, 180 samples : 60 for colour change test, 60 for The transverse strength test and 60 for dimensional stability (warpage test). The samples of each test, were subdivided into three groups each group has 20 specimens according to the denture base materials used as shown in table 1

TABLE (1) The denture base materials

\begin{tabular}{|l|l|l|}
\hline & Material & Manufacturer \\
\hline 1 & $\begin{array}{l}\text { Bre-flex . (thermoplastic) } \\
\text { denture base materials }\end{array}$ & (BREDENT, Germany) \\
\hline 2 & $\begin{array}{l}\text { conventional heat-cured } \\
\text { denture base materials }\end{array}$ & Acrostone , Egypt \\
\hline 3 & Self-cured acrylic resin & Acrostone , Egypt \\
\hline
\end{tabular}

\section{Samples Preparation for colour stability and transverse strength test:}

Total number of 60 rectangle- shaped samples (20 of each of selected materials) were prepared by using a metallic mold of the following dimensions (10 length $\mathrm{x} 10$ width $\mathrm{x} 4 \mathrm{~mm}$ thickness for testing colour stability ${ }^{(19)}$ as well as another 60 rectangleshaped samples (20 of each of selected materials) were prepared on the following dimensions $65 \mathrm{~mm}$ length $\times 10 \mathrm{~mm}$ width $\times 2.5 \mathrm{~mm}$ thickness For transverse strength test ${ }^{(20)}$. Breflex (Thermoplastic) samples were fabricated on the report of the manufacturer's directives using the thermopress injection molding system (Vertex ${ }^{\mathrm{TM}}$ ThermoJect22). The material injected with a pressure of $110 \mathrm{psi}$ at $280^{\circ} \mathrm{C}$. for 20 miutes $^{(21)}$. The samples from heat cured acrylic were constructed on the report of manufacturer' instructions using a compression molding (trial-pack) technique and curing of PMMA acrylic resin performed in water bath at $70^{\circ} \mathrm{C}$ for79 hours followed by $100^{\circ} \mathrm{C}$ for 30 minutes. Selfcured acrylic resin samples were packed in the molds and the polymerization process was carried out at $25^{\circ} \mathrm{C}$ for 10 minutes. After deflasking, all the samples were finished and polished with the use of water to prevent exaggerated heat, which may lead to deformation of the samples. The samples were stored for 24 hours in distilled water at room temperature

\section{Samples Preparation for Dimensional stability (Warpage test)}

Total number of 60 samples (20 of each of selected materials ) were constructed by the use of a sectional maxillary metallic cast which acts as the dimensions of the palate and the edentulous ridge ,It has five fine parallel lines inscribed on its posterior aspect to be used as a reference measuring sites ${ }^{(22)}$. The metallic cast was duplicated using polyvinyl siloxane (Silastic E; Dow Corning, Midland, Mich, USA) to prepare 60 similar standardized sectional casts made from dental stone. Base plate wax of 2 $\mathrm{mm}$ thickness was adapted over each cast and sealed 
well at the peripheries. Flasking and processing performed according to ordinary laboratory techniques and manufacture's directives, to produce 60 sectional maxillary denture bases made from different denture base materials. Deflasking was achieved carefully to prevent damage of casts as well as polishing to prevent raise in temperature which can perform warpage . Dentures were then cautiously seated with mild pressure on the stone cast

\section{Disinfection methods using the microwave radiation}

60 samples of each colour stability, transverse strength and Dimensional stability (Warpage) tests, 20 samples for each denture base materials (Breflex, heatcure and self cure acrylic resin groups) were randomly divided into 4 groups $(n=5)$, according to the exposure to microwave energy and its exposure time as follows: Five control samples (not disinfected), five samples disinfected for 5 minutes, five samples disinfected for 10 minutes and five samples disinfected for 15 minutes .

In disinfection groups radiation in the microwave was done with 650 watts of power. All the samples of test groups of the different denture base materials were placed in glass containers containing $150 \mathrm{ml}$ of distilled water ${ }^{(23)}$.

\section{Colour Measurements}

The color of each sample was measured by using a spectrophotometer (Thermo Fisher Scientific)* (Figure 1) which measured the light absorption of each sample. Each sample was evaluated as regards the color change $(\Delta \mathrm{E})$ by using the International Commission on Illumination (CIE L*a*b*) color concept through the next equation: $\Delta \mathrm{E}=\left[\left(\Delta \mathrm{L}^{*}\right) 2+\right.$ $\left.\left(\Delta \mathrm{a}^{*}\right) 2+\left(\Delta \mathrm{b}^{*}\right) 2\right] 1 / 2$. $^{(24,25)}$.

All samples were assessed for color changes either those disinfected by microwave or without disinfection to evaluate its effectiveness by fixing the samples to the holder of spectrophotometer then turn on the device and the samples were tested. In addition, the changes in the colour of denture bases materials clinically can be quantified by the National Bureau of Standards (NBS) units using the next formula NBS units $=\Delta \mathrm{E} \times 0.92$

\section{Transverse Strength Test:}

The test was carried by using three- points bending on an universal testing machine (Figure2). The devise was supplied with a middle loading plunger and two supports,. The loading plunger was exert force in Newten with speed of $5 \mathrm{~mm} / \mathrm{min}$. placed on the middle of the samples until fracture occurs in acrylic resin groups. Bre-flex samples were not

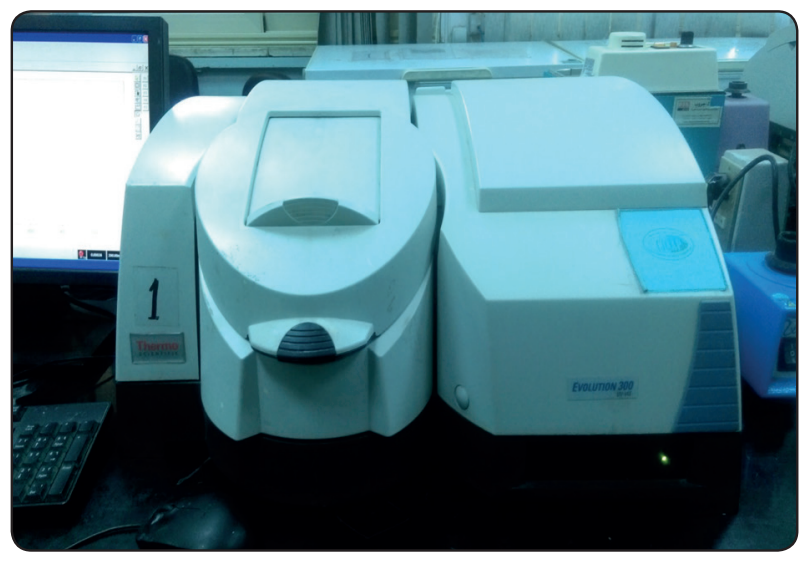

Fig. (1) Spectrophotometer (Thermo Fisher Scientific)*

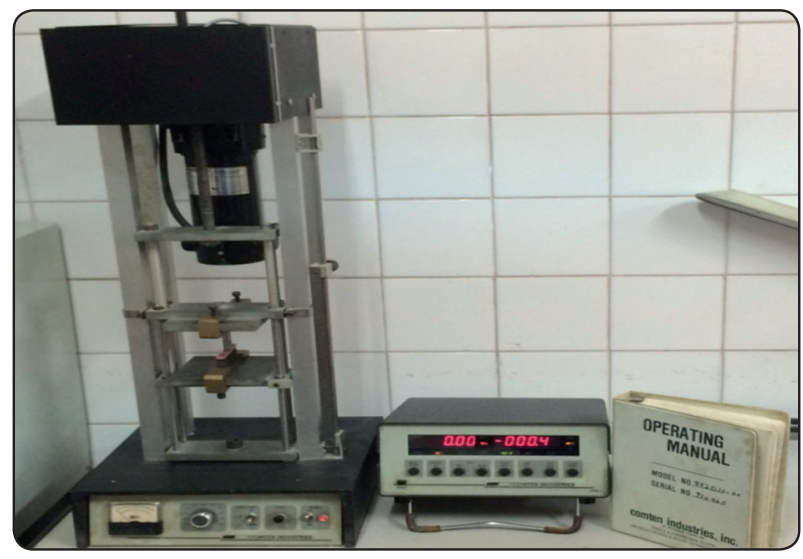

Fig. (2) Universal testing machine**

\footnotetext{
* Madison, WI 53711 USA

** Comten Industries,Inc.St.Petersburg, Florida,USA. Model no942D10-20
} 
fractured, but they were deflected until the samples become as a $U$ shape. The transverse strength were calculated by using the following mathematical equation: $\mathrm{S}=3 \mathrm{PI} / 2 \mathrm{bd} 2 \mathrm{~S}=$ transverse strength (Newton $/ \mathrm{mm} 2) \mathrm{b}=$ width of sample $(\mathrm{mm}) \mathrm{d}=$ depth of sample $(\mathrm{mm}) \mathrm{I}=$ distance between supports $(\mathrm{mm})$ $\mathrm{P}=$ the load at fracture or deflection (Newton). ${ }^{(23)}$

\section{Measuring of (Warpage test)}

The vertical distance between the fitting surface of the finished denture bases and the stone casts was carried by using a Tool- Maker' microscope ** (Figure3) (its least reading was $0.01 \mathrm{~mm})$. The measurement locations were determined along five points, point $\mathrm{C}$ represented the center of the palate, points $\mathrm{R}$ and $\mathrm{L}$ represented the crests of the ridge on both sides, and $\mathrm{A}$ and $\mathrm{B}$ were points half way from the crest of the ridge to the center of the palate. ${ }^{(26)}$ The five palatal location mea-

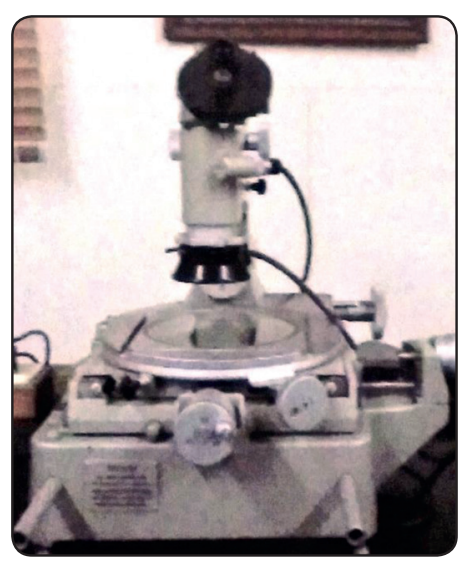

Fig. (3) Tool- Maker' microscope

surements for each cast were averaged into a single measure of dimensional change, for data analysis

Data was collected and analysis of it was done by IBM SPSS software package version 20.0. ANOVA and Post-hoc Tukey's tests. The level of statistical significance was taken as p value $\leq 0.05$.

TABLE (2): Comparison between the different exposure times according to the mean values of color change $(\Delta \mathrm{E})$ and standard deviations in each material

\begin{tabular}{|c|c|c|c|c|c|}
\hline \multirow{2}{*}{$\Delta \mathbf{E}$} & \multirow{2}{*}{$\begin{array}{c}\text { Control } \\
(n=5)\end{array}$} & \multicolumn{3}{|c|}{ Times of microwave disinfection } & \multirow{2}{*}{$\mathbf{F}(\mathbf{p})$} \\
\hline & & 5 minutes $(n=5)$ & 10 minutes $(n=5)$ & 15 minutes $(n=5)$ & \\
\hline \multicolumn{6}{|l|}{ Heat cure } \\
\hline Mean $\pm \mathrm{SD}$ & $3.6 \pm 0.2$ & $3.6 \pm 0.1$ & $3.4 \pm 0.2$ & $3.4 \pm 0.1$ & \multirow{2}{*}{$\begin{array}{c}3.632^{*} \\
\left(0.036^{*}\right)\end{array}$} \\
\hline Median (Min. - Max.) & $3.8(3.3-3.8)$ & $3.6(3.5-3.7)$ & $3.5(3.2-3.5)$ & $3.4(3.3-3.4)$ & \\
\hline $\mathbf{p}_{\text {control }}$ & & 0.971 & 0.125 & $0.049^{*}$ & \\
\hline Sig. bet. grps. & & \multicolumn{3}{|c|}{$\mathrm{p}_{1}=0.257, \mathrm{p}_{2}=0.155, \mathrm{p}_{3}=0.989$} & \\
\hline \multicolumn{6}{|l|}{ Self-cure } \\
\hline Mean $\pm \mathrm{SD}$ & $3.4 \pm 0.04$ & $3.6 \pm 0.1$ & $3.6 \pm 0.2$ & $3.5 \pm 0.2$ & \multirow{2}{*}{$\begin{array}{c}1.441 \\
(0.268)\end{array}$} \\
\hline Median (Min. - Max.) & $3.5(3.4-3.5)$ & $3.6(3.5-3.7)$ & $3.5(3.4-3.9)$ & $3.6(3.1-3.7)$ & \\
\hline \multicolumn{6}{|l|}{ Breflex } \\
\hline Mean \pm SD & $3.4 \pm 0.1$ & $3.5 \pm 0.2$ & $3.5 \pm 0.3$ & $3.4 \pm 0.1$ & 0.485 \\
\hline Median (Min. - Max.) & $3.4(3.3-3.5)$ & $3.5(3.3-3.8)$ & $3.4(3.3-4)$ & $3.5(3.4-3.5)$ & $(0.697)$ \\
\hline
\end{tabular}

F: F for ANOVA test, Pairwise comparison bet. each 2 groups was done using Post Hoc Test (Tukey)

p: $p$ value for comparing between different times in each material

$p_{\text {Control }}: p$ value for comparing between control and each other groups

$p_{1}: p$ value for comparing between 5 minutes and 10 minutes

$p_{2}: p$ value for comparing between 5 minutes and 15 minutes

$p_{3}: p$ value for comparing between 10 minutes and 15 minutes

$*$ : Statistically significant at $p \leq 0.05$

* MSSI Company, West Germany 


\section{RESULTS}

Table 2 and (Graph1) showed the mean values of color change $(\Delta \mathrm{E})$ and standard deviations of denture base materials studied after disinfection by microwave at different exposure times $(5,10$ and 15 minutes)

ANOVA test detected no significant color change in microwaved samples of thermoplastic (breflex), self-cure at all the intervals and heat cure acrylic resins only at (5 and 10 minutes) compared to the control groups. However, a significant change in the color was found in heat cure at 15 minutes $(\mathrm{P}=0.049)$

Post hoc test for comparisons between different times of disinfection in each material showed no significant changes in color for all the tested samples of the three materials. (Table 3) and (Graph2) showed comparison between the different studied denture base materials according to color change $(\Delta \mathrm{E})$ in the samples that disinfected with microwave at different intervals $(5,10,15$ minutes.) as well as control groups. It was found that there is no significant color change between them.

TABLE (3): Comparison between the different studied materials according to color change $(\Delta \mathrm{E})$ at different exposure times

\begin{tabular}{|c|c|c|c|c|}
\hline \multirow{2}{*}{$\begin{array}{c}\text { Times of microwave } \\
\text { disinfection }\end{array}$} & \multicolumn{3}{|c|}{$\Delta \mathbf{E}$} & \multirow{2}{*}{$\mathbf{F}(\mathbf{p})$} \\
\hline & Heat cure $(n=5)$ & Self-cure $(n=5)$ & Breflex $(n=5)$ & \\
\hline \multicolumn{5}{|l|}{ Control } \\
\hline Mean \pm SD. & $3.6 \pm 0.2$ & $3.4 \pm 0.04$ & $3.4 \pm 0.1$ & \multirow{2}{*}{$\begin{array}{r}3.113 \\
(0.081) \\
\end{array}$} \\
\hline Median (Min. - Max.) & $3.8(3.3-3.8)$ & $3.5(3.4-3.5)$ & $3.4(3.3-3.5)$ & \\
\hline \multicolumn{5}{|l|}{5 minutes } \\
\hline Mean \pm SD. & $3.6 \pm 0.1$ & $3.6 \pm 0.1$ & $3.5 \pm 0.2$ & \multirow{2}{*}{$\begin{array}{c}0.705 \\
(0.514) \\
\end{array}$} \\
\hline Median (Min. - Max.) & $3.6(3.5-3.7)$ & $3.6(3.5-3.7)$ & $3.5(3.3-3.8)$ & \\
\hline \multicolumn{5}{|l|}{10 minutes } \\
\hline Mean \pm SD. & $3.4 \pm 0.2$ & $3.6 \pm 0.2$ & $3.5 \pm 0.3$ & \multirow{2}{*}{$\begin{array}{r}1.729 \\
(0.219) \\
\end{array}$} \\
\hline Median (Min. - Max.) & $3.5(3.2-3.5)$ & $3.5(3.4-3.9)$ & $3.4(3.3-4)$ & \\
\hline \multicolumn{5}{|l|}{15 minutes } \\
\hline Mean \pm SD & $3.4 \pm 0.1$ & $3.5 \pm 0.2$ & $3.4 \pm 0.1$ & \multirow{2}{*}{$\begin{array}{c}0.444 \\
(0.651)\end{array}$} \\
\hline Median (Min. - Max.) & $3.4(3.3-3.4)$ & $3.6(3.1-3.7)$ & $3.5(3.4-3.5)$ & \\
\hline
\end{tabular}

F: F for ANOVA test, Pairwise comparison bet. each 2 groups was done using Post Hoc Test (Tukey)

p: $p$ value for comparing between different materials in each time

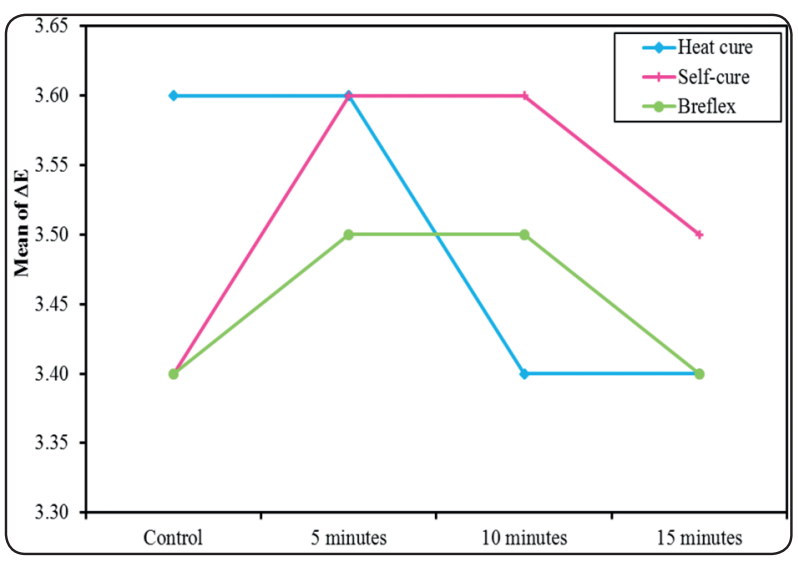

Fig. (1): Comparison between the different exposure times according to the mean values of color change $(\Delta \mathrm{E})$ and standard deviations in each material

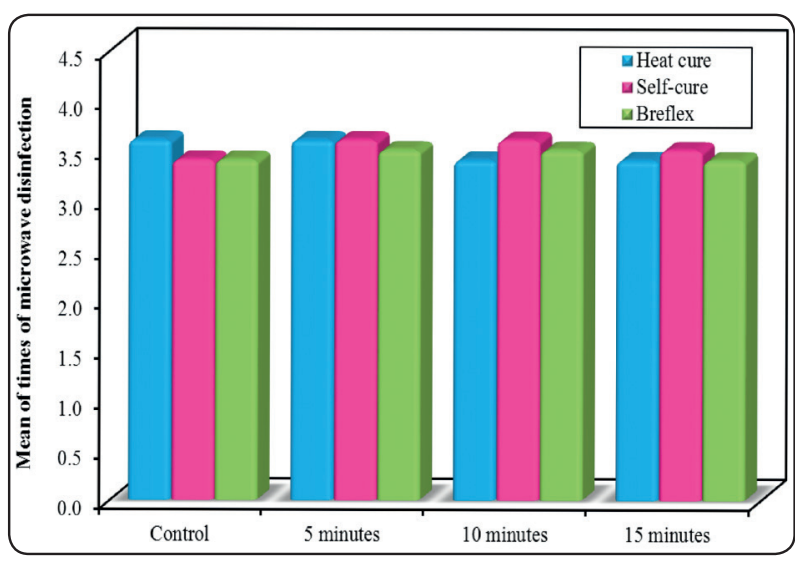

Fig. (2): Comparison between the different studied materials according to color change $(\Delta \mathrm{E})$ at different exposure times 
Table 4 (Graph3) shows the means and standard deviations of National Bureau of Standards (NBS) units for denture base materials after disinfected by microwave in different exposure time. The results revealed that when using ANOVA test it was detected that no significant color change in microwaved samples of thermoplastic (breflex), heat cure and self-cure acrylic resins at all the intervals compared to the control groups. As well, when comparing between different times of disinfection in each material using Post hoc test showed no significant changes in color for all the tested samples of the three materials.

In addition, When comparing between the different studied material according to NBS in each time in (Table 5) and (Graph 4) showed no

TABLE (4): Comparison between the different exposure times according to the mean values and standard deviations of NBS in each material

\begin{tabular}{|c|c|c|c|c|c|}
\hline \multirow{2}{*}{ NBS } & \multirow{2}{*}{$\begin{array}{c}\text { Control } \\
(\mathbf{n = 5}\end{array}$} & $\begin{array}{c}\mathbf{5} \text { minutes } \\
(\mathbf{n = 5})\end{array}$ & $\begin{array}{c}\mathbf{1 0} \text { minutes } \\
(\mathbf{n = 5})\end{array}$ & $\begin{array}{c}\mathbf{1 5} \text { minutes } \\
(\mathbf{n}=\mathbf{5})\end{array}$ & \multirow{2}{*}{ F $(\mathbf{p})$} \\
\cline { 3 - 5 } & & & & & \\
\hline Heat cure & & $3.3 \pm 0.1$ & $3.1 \pm 0.2$ & $3.2 \pm 0.2$ & 1.327 \\
\hline Mean \pm SD. & $3.3 \pm 0.2$ & $3.3(3.2-3.6)$ & $3.1(3-3.4)$ & $3.2(2.9-3.5)$ & $(0.300)$ \\
\hline Median (Min. - Max.) & $3.5(3.1-3.5)$ & & & & \\
\hline Self-cure & & $3.2 \pm 0.05$ & $3.3 \pm 0.3$ & $3.3 \pm 0.3$ & 1.130 \\
\hline Mean \pm SD. & $3.2 \pm 0.04$ & $3.3(3.3-3.4)$ & $3.2(3.2-3.8)$ & $3.3(2.9-3.6)$ & $(0.367)$ \\
\hline Median (Min. - Max.) & $3.2(3.1-3.2)$ & & & & \\
\hline Breflex & & $3.1 \pm 0.2$ & $3.2 \pm 0.2$ & $3.2 \pm 0.1$ & 0.490 \\
\hline Mean \pm SD. & $3.1 \pm 0.1$ & $3.2(3-3.5)$ & $3.2(3.1-3.7)$ & $3.2(3.1-3.3)$ & $(0.694)$ \\
\hline Median (Min. - Max.) & $3.1(3-3.2)$ & & & & \\
\hline
\end{tabular}

F: F for ANOVA test, Pairwise comparison bet. each 2 groups was done using Post Hoc Test (Tukey) p: $p$ value for comparing between different times in each material

TABLE (5): Comparison between the different studied materials according to NBS at different exposure times.

\begin{tabular}{|c|c|c|c|c|}
\hline \multirow{2}{*}{$\begin{array}{c}\text { Times of microwave } \\
\text { disinfection }\end{array}$} & \multicolumn{3}{|c|}{ NBS } & \multirow[b]{2}{*}{$\mathbf{F}(\mathbf{p})$} \\
\hline & $\begin{array}{l}\text { Heat cure } \\
\quad(\mathbf{n}=5)\end{array}$ & $\begin{array}{c}\text { Self-cure } \\
(n=5)\end{array}$ & $\begin{array}{c}\text { Breflex } \\
(n=5)\end{array}$ & \\
\hline \multicolumn{5}{|l|}{ Control } \\
\hline Mean \pm SD. & $3.3 \pm 0.2$ & $3.2 \pm 0.04$ & $3.1 \pm 0.1$ & \multirow{2}{*}{$\begin{array}{c}3.074 \\
(0.084) \\
\end{array}$} \\
\hline Median (Min. - Max.) & $3.5(3.1-3.5)$ & $3.2(3.1-3.2)$ & $3.1(3-3.2)$ & \\
\hline \multicolumn{5}{|l|}{5 minutes } \\
\hline Mean \pm SD. & $3.3 \pm 0.1$ & $3.2 \pm 0.05$ & $3.1 \pm 0.2$ & \multirow{2}{*}{$\begin{array}{c}1.084 \\
(0.369)\end{array}$} \\
\hline Median (Min. - Max.) & $3.3(3.2-3.6)$ & $3.3(3.3-3.4)$ & $3.2(3-3.5)$ & \\
\hline \multicolumn{5}{|l|}{10 minutes } \\
\hline Mean \pm SD. & $3.1 \pm 0.2$ & $3.3 \pm 0.3$ & $3.2 \pm 0.2$ & \multirow{2}{*}{$\begin{array}{r}1.106 \\
(0.363) \\
\end{array}$} \\
\hline Median (Min. - Max.) & $3.1(3-3.4)$ & $3.2(3.2-3.8)$ & $3.2(3.1-3.7)$ & \\
\hline \multicolumn{5}{|l|}{15 minutes } \\
\hline Mean \pm SD. & $3.2 \pm 0.2$ & $3.3 \pm 0.3$ & $3.2 \pm 0.1$ & \multirow{2}{*}{$\begin{array}{c}0.438 \\
(0.655)\end{array}$} \\
\hline Median (Min. - Max.) & $3.2(2.9-3.5)$ & $3.3(2.9-3.6)$ & $3.2(3.1-3.3)$ & \\
\hline
\end{tabular}

F: F for ANOVA test, Pairwise comparison bet. each 2 groups was done using Post Hoc Test (Tukey) p: $p$ value for comparing between different materials in each time 


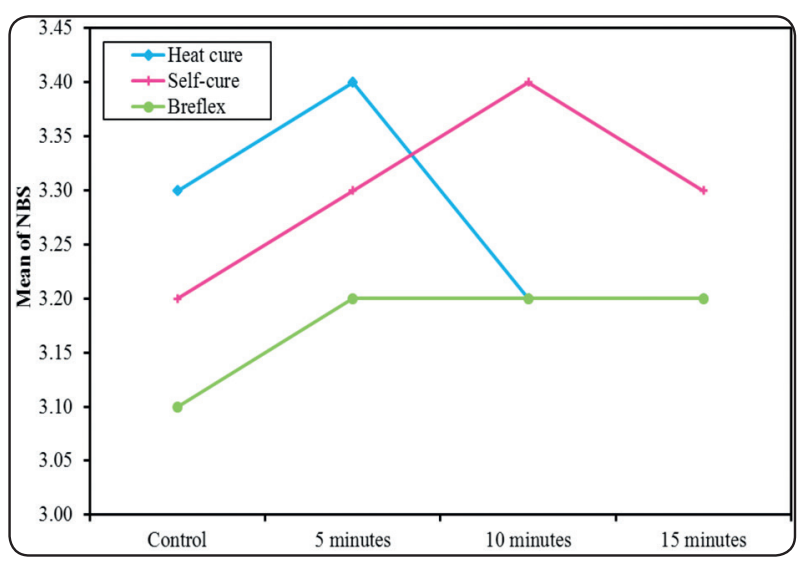

Fig. (3): Comparison between the different exposure times according to the mean values and standard deviations of NBS in each material

significant color change between the samples that disinfected with microwave at different intervals $(5,10,15$ minutes.) as well as control groups.

The transverse strength of the samples of different studied denture base materials that disinfected by microwave is generally reduced between the different groups (5, 10 and 15 minutes) of the same material however control group samples had the highest mean values while disinfection of the samples at 15 minutes had the lowest mean value as shown in (Table 6) and (Graph 5) . The statistically analysis indicated that regarding the microwave disinfected samples there is no significant difference in transverse strength values between the different groups of the same material

(Table 7) and (Graph 6) show comparison between the different studied denture base materials according to transverse strength (MPa). It was found that in control groups there is no significant difference in transverse strength between heat cure acrylic resin and self cure acrylic resin .Also, their is significant differences of flexural strength between bre-flex and heat cure as well as self cure, however bre-flex is higher than both materials. In addition, the samples that disinfected with microwave at different intervals $(5,10,15$ minutes $)$ displayed that there is a significant differences between heat cure

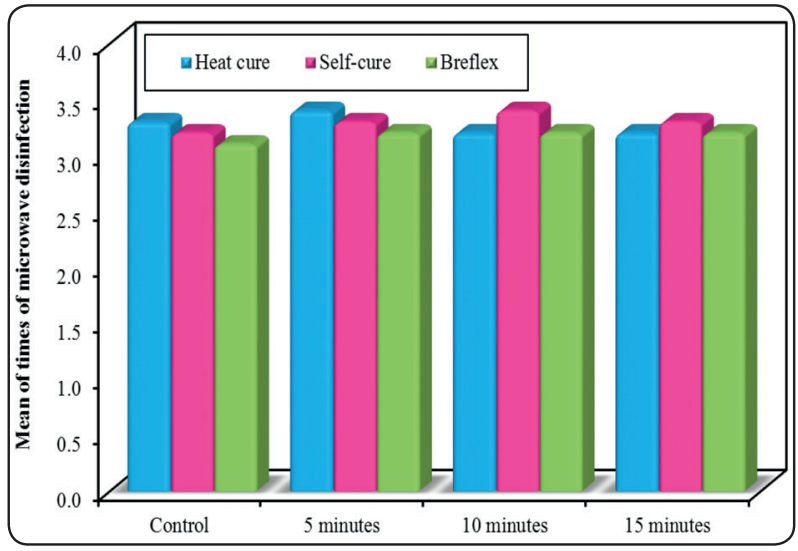

Fig. (4): Comparison between the different studied materials according to NBS at different exposure times.

acrylic resin and self cure acrylic resin. Moreover, stated a highly significant difference between Breflex and heat cure samples, as well as too highly significant differences between Bre-flex and self cure (Table 8) and (Graph7) show average of mean values of the dimension changes (warpage) of posterior palatal seal (A,B,C,D \& E )of the studied samples of heat cure and self cure acrylic resins that disinfected by microwave is increased between the different groups (5,10 and 15 minutes) however control group samples had the lowest mean values of gap spaces while disinfection of the samples at 15 minutes had the highest mean value of gap.

In contrary to the previous results the samples Breflex thermoplastic resin showed decrease in the warpage between the different groups. However, control group samples had the highest mean values of gap spaces while disinfection of the samples at 15 minutes had the lowest mean value of gap. The statistically analysis indicated that regarding the microwave disinfected samples there is no significant difference in mean values of the gap of all the groups which disinfected at 5, 10 and 15 minutes when compared to each other as well as to the control groups in the same material at $p \leq 0.05$.

In comparing the samples of different denture base materials in (Table 9) and (Graph8) it was 
TABLE (6): Comparison between the different studied groups according to flexural strength (MPa) in each material

\begin{tabular}{|c|c|c|c|c|c|}
\hline \multirow[b]{2}{*}{ Acrylic resin material } & \multicolumn{4}{|c|}{ Times of microwave disinfection } & \multirow[b]{2}{*}{$\mathbf{F}(\mathbf{p})$} \\
\hline & $\begin{array}{c}\text { Control } \\
(n=5)\end{array}$ & $\begin{array}{c}5 \text { minutes } \\
(n=5)\end{array}$ & $\begin{array}{c}10 \text { minutes } \\
(n=5)\end{array}$ & $\begin{array}{c}\text { minutes } 15 \\
(n=5)\end{array}$ & \\
\hline \multicolumn{6}{|l|}{ Heat cure } \\
\hline Mean \pm SD & $122.137 .7 \pm$ & $118.234 \pm$ & $110.436 .7 \pm$ & $96.922 .9 \pm$ & \multirow{2}{*}{$\begin{array}{c}0.558 \\
(0.650) \\
\end{array}$} \\
\hline Median (Min. - Max.) & $115.2(78.5-165.4)$ & $114.1(77.5-155.2)$ & $104(70.2-170.2)$ & $96.9(66.4-130.7)$ & \\
\hline \multicolumn{6}{|l|}{ Self-cure } \\
\hline Mean \pm SD. & $66.316 .1 \pm$ & $6617.4 \pm$ & $58.215 \pm$ & $44.67 .1 \pm$ & \multirow{2}{*}{$\begin{array}{r}2.455 \\
(0.101) \\
\end{array}$} \\
\hline Median (Min. - Max.) & $63.1(45.285 .2-)$ & $64.3(42.584 .1-)$ & $54.1(42.682 .1-)$ & $41.5(3752.5-)$ & \\
\hline \multicolumn{6}{|l|}{ Thermo-elastic } \\
\hline Mean \pm SD. & $212.648 \pm$ & $205.337 .2 \pm$ & $193.121 .4 \pm$ & $181.815 .3 \pm$ & \multirow[b]{2}{*}{$\begin{array}{c}0.843 \\
(0.490)\end{array}$} \\
\hline Median (Min. - Max.) & 190.2(170.6-288.1) & $189.5(169-257.1)$ & $189.1(170.5-228.6)$ & $\begin{array}{c}178.3(165.4- \\
205.6)\end{array}$ & \\
\hline
\end{tabular}

F: F for ANOVA test, Pairwise comparison bet. each 2 groups was done using Post Hoc Test (Tukey) p: $p$ value for comparing between different times in each material

$p_{\text {Control }} p$ value for comparing between control and each other groups

$p_{1}: p$ value for comparing between 5 minutes and 10 minutes $p_{2}: p$ value for comparing between 5 minutes and 15 minutes

$p_{3}: p$ value for comparing between 10 minutes and 15 minutes $\quad *$ : Statistically significant at $p \leq 0.05$

TABLE (7): Comparison between the different studied groups according to flexural strength (MPa) in each time

\begin{tabular}{|c|c|c|c|c|}
\hline \multirow{2}{*}{$\begin{array}{c}\text { Times of microwave } \\
\text { disinfection }\end{array}$} & \multicolumn{3}{|c|}{ Acrylic resin material } & \multirow[b]{2}{*}{$\mathbf{F}(\mathbf{p})$} \\
\hline & $\begin{array}{l}\text { Heat cure } \\
(\mathrm{n}=5)\end{array}$ & $\begin{array}{c}\text { Self-cure } \\
(n=5)\end{array}$ & $\begin{array}{c}\text { Thermo-elastic } \\
(n=5)\end{array}$ & \\
\hline \multicolumn{5}{|l|}{ Control } \\
\hline Mean \pm SD. & $122.1 \pm 37.7$ & $66.3 \pm 16.1$ & $212.6 \pm 48$ & \multirow{2}{*}{$\begin{array}{c}20.524^{*} \\
\left(<0.001^{*}\right)\end{array}$} \\
\hline Median (Min. - Max.) & $115.2(78.5-165.4)$ & $63.1(45.2-85.2)$ & $190.2(170.6-288.1)$ & \\
\hline Sig. bet. grps & \multicolumn{3}{|c|}{$\mathrm{p}_{1}=0.076, \mathrm{p}_{2}=0.005^{*}, \mathrm{p}_{3}<0.001^{*}$} & \\
\hline \multicolumn{5}{|l|}{5 minutes } \\
\hline Mean \pm SD. & $118.2 \pm 34$ & $66 \pm 17.4$ & $205.3 \pm 37.2$ & \multirow{2}{*}{$\begin{array}{c}26.176^{*} \\
\left(<0.001^{*}\right) \\
\end{array}$} \\
\hline Median (Min. - Max.) & $114.1(77.5-155.2)$ & $64.3(42.5-84.1)$ & $189.5(169-257.1)$ & \\
\hline Sig. bet. grps & \multicolumn{3}{|c|}{$\mathrm{p}_{1}=0.048^{*}, \mathrm{p}_{2}=0.002^{*}, \mathrm{p}_{3}<0.001^{*}$} & \\
\hline \multicolumn{5}{|l|}{10 minutes } \\
\hline Mean \pm SD. & $110.4 \pm 36.7$ & $58.2 \pm 15$ & $193.1 \pm 21.4$ & \multirow{2}{*}{$\begin{array}{c}34.182^{*} \\
\left(<0.001^{*}\right) \\
\end{array}$} \\
\hline Median (Min. - Max.) & 104(70.2-170.2) & $54.1(42.6-82.1)$ & 189.1(170.5-228.6) & \\
\hline Sig. bet. grps & \multicolumn{3}{|c|}{$\mathrm{p}_{1}=0.020^{*}, \mathrm{p}_{2}=0.001^{*}, \mathrm{p}_{3}<0.001^{*}$} & \\
\hline \multicolumn{5}{|l|}{15 minutes } \\
\hline Mean \pm SD & $96.9 \pm 22.9$ & $44.6 \pm 7.1$ & $181.8 \pm 15.3$ & \multirow{3}{*}{$\begin{array}{c}88.690^{*} \\
\left(<0.001^{*}\right)\end{array}$} \\
\hline Median (Min. - Max.) & $96.9(66.4-130.7)$ & $41.5(37-52.5)$ & 178.3(165.4-205.6) & \\
\hline Sig. bet. grps & & $1^{*}, \mathrm{p}_{2}<0.001^{*}, \mathrm{p}_{3}$ & & \\
\hline
\end{tabular}

F: F for ANOVA test, Pairwise comparison bet. each 2 groups was done using Post Hoc Test (Tukey)

p: $p$ value for comparing between different materials in each time

p1: $p$ value for comparing between Heat cure and Self-cure p2: p value for comparing between Heat cure and Thermo-elastic p3: $p$ value for comparing between Self-cure and Thermo-elastic $\quad *$ : Statistically significant at $p \leq 0.05$ 
found that the average of the mean values of the dimension changes (warpage) of posterior palatal seal gap in heat cure is lower than self-cure either samples disinfected with microwave or not disinfected but the difference is not significant

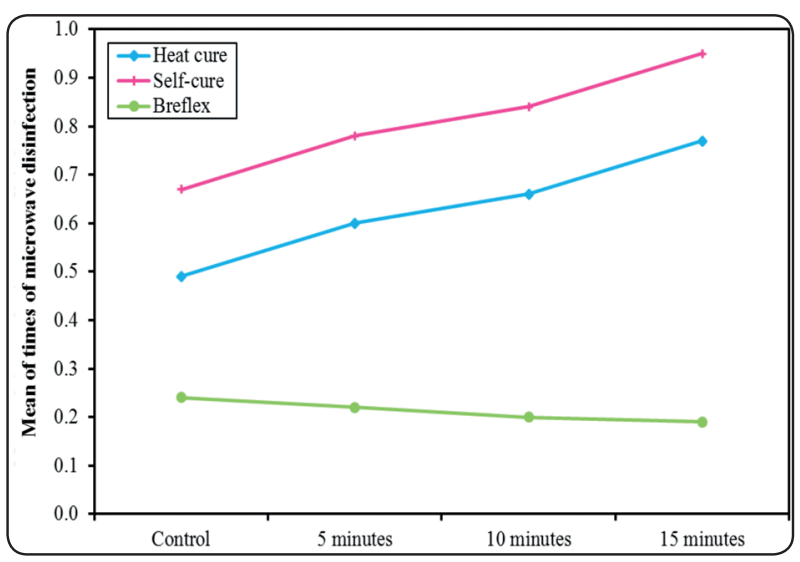

Graph (5): Comparison between the different studied groups according to flexural strength (MPa) in each material
Moreover, in disinfected and non-disinfected samples displayed that there is lower in dimension changes in Bre-flex in comparison to heat cure as well as self cure. Bre-flex demonstrated a highly significant difference with heat cure samples, as well as too highly significant differences with self cure

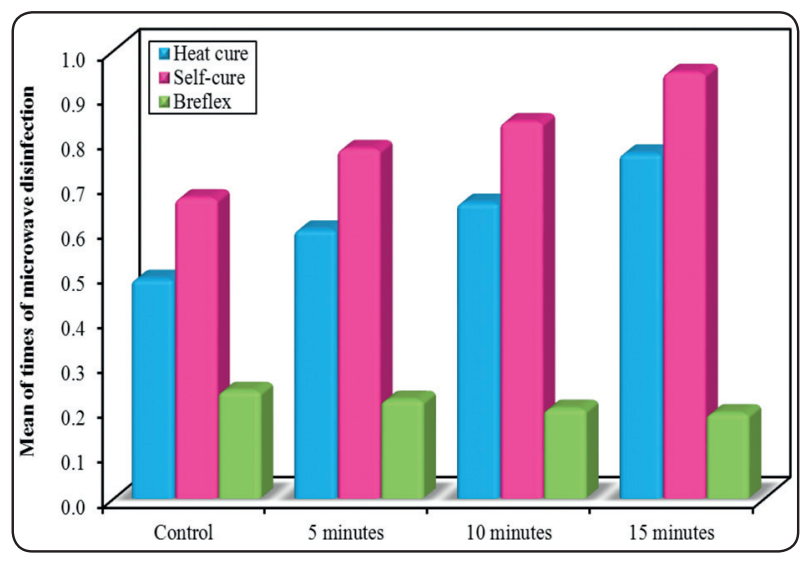

Graph (6): Comparison between the different studied groups according to flexural strength $(\mathrm{MPa})$ in each time

Table (8): Comparison between the different studied groups according to average of the mean values of the dimension changes at the five palatal measurements in the same material

\begin{tabular}{|c|c|c|c|c|c|}
\hline \multirow[b]{2}{*}{ Acrylic resin material } & \multicolumn{4}{|c|}{ Times of microwave disinfection } & \multirow[b]{2}{*}{$\mathbf{F}(\mathbf{p})$} \\
\hline & $\begin{array}{c}\text { Control } \\
(n=5)\end{array}$ & $\begin{array}{c}5 \text { minutes } \\
(n=5)\end{array}$ & $\begin{array}{c}10 \text { minutes } \\
(n=5)\end{array}$ & $\begin{array}{c}15 \text { minutes } \\
(\mathrm{n}=5)\end{array}$ & \\
\hline \multicolumn{6}{|l|}{ Heat cure } \\
\hline Mean \pm SD & $0.49 \pm 0.14$ & $0.60 \pm 0.23$ & $0.66 \pm 0.10$ & $0.77 \pm 0.22$ & \multirow{2}{*}{$\begin{array}{c}2.140 \\
(0.135)\end{array}$} \\
\hline Median (Min. - Max.) & $0.52(0.35-0.68)$ & $0.56(0.36-0.96)$ & $0.71(0.50-0.74)$ & $0.71(0.61-1.15)$ & \\
\hline \multicolumn{6}{|l|}{ Self-cure } \\
\hline Mean \pm SD & $0.67 \pm 0.17$ & $0.78 \pm 0.22$ & $0.84 \pm 0.29$ & $0.95 \pm 0.16$ & \multirow{2}{*}{$\begin{array}{c}1.529 \\
(0.245)\end{array}$} \\
\hline Median (Min. - Max.) & $0.65(0.48-0.94)$ & $0.78(0.53-1.06)$ & $0.93(0.54-1.21)$ & $0.96(0.73-1.16)$ & \\
\hline \multicolumn{6}{|l|}{ Thermo-elastic } \\
\hline Mean \pm SD & $0.24 \pm 0.13$ & $0.22 \pm 0.03$ & $0.20 \pm 0.07$ & $0.19 \pm 0.06$ & \multirow{2}{*}{$\begin{array}{c}0.227 \\
(0.876)\end{array}$} \\
\hline Median (Min. - Max.) & $0.27(0.10-0.42)$ & $0.20(0.19-0.26)$ & $0.16(0.15-0.32)$ & $0.19(0.13-0.28)$ & \\
\hline
\end{tabular}


TABLE (9): Comparison between the different studied groups according to average of the mean values of the dimension changes at the five palatal measurements in the same material in each time

\begin{tabular}{|c|c|c|c|c|}
\hline \multirow{2}{*}{$\begin{array}{c}\text { Times of microwave } \\
\text { disinfection }\end{array}$} & \multicolumn{3}{|c|}{ Acrylic resin material } & \multirow[b]{2}{*}{$\mathbf{F}(\mathbf{p})$} \\
\hline & $\begin{array}{l}\text { Heat cure } \\
\quad(\mathbf{n}=5)\end{array}$ & $\begin{array}{l}\text { Self-cure } \\
(\mathbf{n}=5)\end{array}$ & $\begin{array}{l}\text { Thermo-elastic } \\
\qquad(\mathrm{n}=5)\end{array}$ & \\
\hline \multicolumn{5}{|l|}{ Control } \\
\hline Mean \pm SD. & $0.49 \pm 0.14$ & $0.67 \pm 0.17$ & $0.24 \pm 0.13$ & \multirow{2}{*}{$\begin{array}{l}10.801^{*} \\
\left(0.002^{*}\right)\end{array}$} \\
\hline Median (Min. - Max.) & $0.52(0.35-0.68)$ & $0.65(0.48-0.94)$ & $0.27(0.10-0.42)$ & \\
\hline Sig. bet. Grps & \multicolumn{3}{|c|}{$\mathrm{p}_{1}=0.174, \mathrm{p}_{2}=0.047^{*}, \mathrm{p}_{3}=0.002^{*}$} & \\
\hline \multicolumn{5}{|l|}{5 minutes } \\
\hline Mean \pm SD & $0.60 \pm 0.23$ & $0.78 \pm 0.22$ & $0.22 \pm 0.03$ & \multirow{2}{*}{$\begin{array}{l}11.468^{*} \\
\left(0.002^{*}\right)\end{array}$} \\
\hline Median (Min. - Max.) & $0.56(0.36-0.96)$ & $0.78(0.53-1.06)$ & $0.20(0.19-0.26)$ & \\
\hline Sig. bet. grps & \multicolumn{3}{|c|}{$\mathrm{p}_{1}=0.316, \mathrm{p}_{2}=0.020^{*}, \mathrm{p}_{3}=0.001^{*}$} & \\
\hline \multicolumn{5}{|l|}{10 minutes } \\
\hline Mean \pm SD & $0.66 \pm 0.10$ & $0.84 \pm 0.29$ & $0.20 \pm 0.07$ & \multirow{2}{*}{$\begin{array}{c}16.469^{*} \\
\left(<0.001^{*}\right)\end{array}$} \\
\hline Median (Min. - Max.) & $0.71(0.50-0.74)$ & $0.93(0.54-1.21)$ & $0.16(0.15-0.32)$ & \\
\hline Sig. bet. grps & \multicolumn{3}{|c|}{$\mathrm{p}_{1}=0.296, \mathrm{p}_{2}=0.005^{*}, \mathrm{p}_{3}<0.001^{*}$} & \\
\hline \multicolumn{5}{|l|}{15 minutes } \\
\hline Mean \pm SD & $0.77 \pm 0.22$ & $0.95 \pm 0.16$ & $0.19 \pm 0.06$ & \multirow{3}{*}{$\begin{array}{c}30.454^{*} \\
\left(<0.001^{*}\right)\end{array}$} \\
\hline Median (Min. - Max.) & $0.71(0.61-1.15)$ & $0.96(0.73-1.16)$ & $0.19(0.13-0.28)$ & \\
\hline Sig. bet. grps & \multicolumn{3}{|c|}{$\mathrm{p}_{1}=0.224, \mathrm{p}_{2}<0.001^{*}, \mathrm{p}_{3}<0.001^{*}$} & \\
\hline
\end{tabular}

F: F for ANOVA test, Pairwise comparison bet. each 2 groups was done using Post Hoc Test (Tukey)

$p: p$ value for comparing between different materials in each time

$p_{1}: p$ value for comparing between Heat cure and Self-cure

$p_{2}: p$ value for comparing between Heat cure and Thermo-elastic

$p_{3}$ : $p$ value for comparing between Self-cure and Thermo-elastic

*: Statistically significant at $p \leq 0.05$

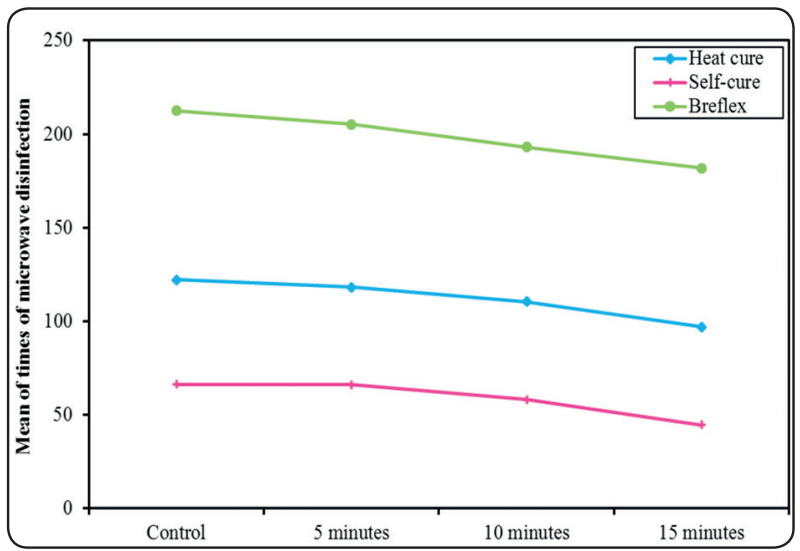

Graph (7): Comparison between the different studied groups according to dimension changes in the same material

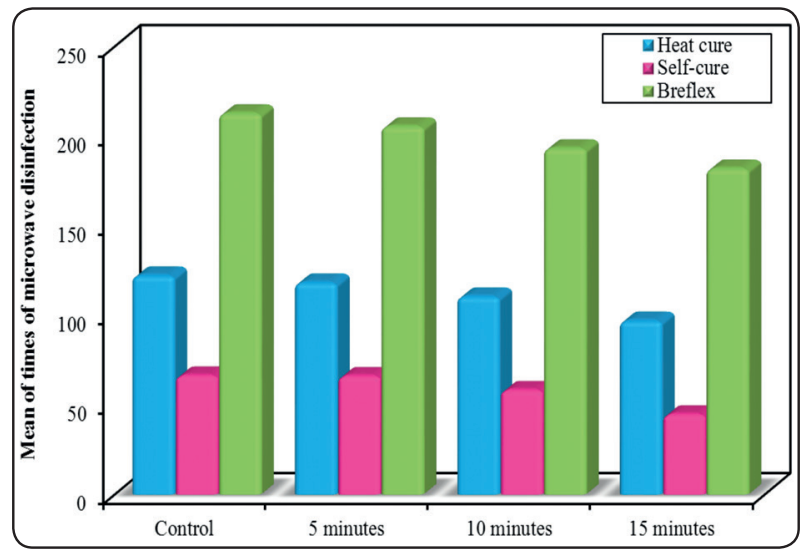

Graph (8): Comparison between the different studied groups according to dimension changes in each time 


\section{DISCUSSION}

This study evaluates the effect of different exposure times of microwave on the colour stability, flexural strength and the dimensional changes of the Bre-flex (thermoplastic resin) and compare it with two types of conventional acrylic resin (Heat cure acrylic resin and Self-cure acrylic resin )

Taken into consideration that the denture base materials should simulate the natural looking of supporting tissues, pigmentation and colour stability of that materials are related properties ${ }^{(27,28)}$. In this concept, the colour stability may attribute the success or failure of the dentures since aesthetics can be the main importance of the patient.

This study's results displayed that microwave disinfection did not significantly change the color of all denture materials in comparison to the control group, while significant differences were found only with heat cure acrylic resin at 15 minutes microwave disinfection

This effect of water on heat cure was also described by Hong, et al. (2009) ${ }^{(29)}$. Who attributed the greater changes in the color due to the length of the immersion time. These changes may be due to the decrease of staining materials by the direct influence of microwaves on a greater spreading of the molecules of water in the polymethyl methacrylate matrix which can allow some of which additionally connect permanently to the high energy places of the polymer ${ }^{(30)}$.

Another explanation, The colour changes of the samples may due to the increase temperature of the material ${ }^{(31,32)}$.

In the literature, there is no sufficient information occurs about the effectiveness of microwave on the color of thermoplastic and conventional acrylic resins denture base materials.

A recent study was performed by Polychronakis $\mathrm{N}$ et al (2018) ${ }^{(33)}$, to assessed the Influence of a long- term of repeated microwave $(450 \mathrm{~W}$ for 3 minutes daily disinfection for 224 days) on the stability of color, translucency and dimension of thermoplastic (Valplast) and (Vertex Rapid Simplified) PMMA resins denture base materials.

They concluded that using of repeated long-term microwaving has effectiveness on changing of the color, translucency, and dimension of both materials which conflict to the present study. On the other hand, they claimed that there were no color changes between (Valplast) and (Vertex Rapid Simplified) PMMA resins denture base materials when comparing between them, Which in agreement with the present study.

Other study performed by Polychronakis et (2014) ${ }^{(34)}$, who estimated the influence of two denture cleansing techniques using (peroxide cleansers) Val-Clean alone and Corega in addition to microwave at $450 \mathrm{~W}$ for 2 min on Valplast(nylon) and(Paladon 65) heatcured denture base materials as regards color, 3D roughness surface, and gloss once daily for an interval 30 days. The results of this study displayed that cleansing technique had no effect on color stability in test group in comparing to the control group in the same material which is in agreement with the present study, while their effectiveness on Valplast was greater than Paladon 65 and clinically they were perceptible which conflict with the present study.

According to the NBS parameters, $\leq 3.3$ is taken into consideration as a clinical assessment in colour change ${ }^{(35)}$. In this concept, the colour change showed by all the denture base materials was clinically accepted because the higher NBS value found was 3.3 (Table4)

This findings were agreement and conflicted by Goiato(2013) ${ }^{(36)}$, who evaluated the influence of disinfection using (microwave $4 \%$ chlorhexidine, Efferdent, and $1 \%$ hypochlorite ) in addition, thermal cycling and on the colour change of four different types of acrylic resin denture base materials. They 
concluded that disinfection and the thermal cycling methods are significantly influenced the stability of the colours of the samples. while all values gained from all the brands of acrylic resins were within acceptable clinical parameters.

Flexural strength describes the loading that occurs on the denture during mastication. Clinically, (37) The reduction of flexural strength during microwave disinfection could make the material more fragile and so leads to the incidence of cracks and fracture.

The results of this research showed that microwave disinfection caused reduction in the transverse strength values of different tested samples of denture base materials (Heat cure acrylic resin, Self-cure acrylic resin and Bre-flex thermoplastic resin). However, the samples of the control groups had the highest mean values while the samples of test group (microwave disinfection) at 15 minutes had the lowest mean value. This reduction was insignificant at different time exposures $(5,10$ and 15 minutes) which may referred to the suitable power of microwave $(650 \mathrm{~W})$ as well as the exposure times used in this study which proved in many studies that displayed the power voltage higher than 850 $\mathrm{W}$ and irradiation time above $15 \mathrm{~min}$ appeared to be the main reason harmful effect of dentures ${ }^{(38,39)}$. In addition, the irradiated samples of the study were placed in glass containers containing $150 \mathrm{ml}$ of distilled water to obtained uniform heating of the materials, avoid overheating the denture base materials and/or causing damage to the microwave itself $^{(7)}$.

These results are in agreement with Ali AM and Raghdaa KJ (2011) ${ }^{(6)}$. Who found that recurrent microwave radiation of valplast and heat cure samples displayed little but no significant reduction in transverse strength if they are disinfected using microwave for 3 minutes at $680 \mathrm{~W}$

In addition , Konchada et $\mathrm{al}^{(37}$ ) (2013) supported The results of this study because they found that no changing in flexural strength when they used as disinfectant to the dentures at $650 \mathrm{~W}$ for $5 \mathrm{~min}$, while soaking in water The same results were stated in a study performed by Ribeiro et al. ${ }^{(40)}$ using (650 W/ 1-5 min immersed in water) .

In contrary, to these results, Consani et al. ${ }^{(41)}$ concluded that the microwave disinfection at 650 W for $3 \mathrm{~min}$ in water) had no variance in the flexural strength between disinfected and non-disinfected samples.

Moreover, Hamouda and Ahmed ${ }^{(9)}$ shown that both 5 and 15 minutes of microwave disinfection at $750 \mathrm{~W}$, either in dry condition, or soacking in water created a reduction of the flexural properties of denture base acrylic resins and stated that this method is not agreeable for dentures.

Bre-flex thermoplastic resin used in this study displayed higher significant effect on the transverse strength values in comparison with both heat cure and self cure acrylic resin either in control groups or in test groups in each disinfection exposure times with microwave

In control groups this difference may be due to the difference in their chemical structure since the Bre-flex have polyamide linkage which make it have more flexibility and resistance to fracture than acrylic resin denture base materials ${ }^{(16)}$.

These results are in agreement with Soygun et al. ${ }^{(42)}$ (2013)who study some mechanical properties of polyamide (Valplast) and compared with the conventional PMMA (control) and fiber reinforced PMMA denture base materials. The results displayed that the highest transverse strength occurred in the (Valplast) polyamide denture base material

Takabayashi $(2010)^{(17)}$ conflict with these study as he found that the flexural strength of three polyamide type materials (Valplast, Lucitone FRS and Flexite Supreme) were lower than conventional polymethyl methacrylate (Acron).the same results explained by Ucar et al . ${ }^{(43)}$ (2012) 
In test groups The significant higher in transverse strength values for Bre-flex thermoplastic resin be due to the effect of microwave irradiation which caused to fast heating and boiling of the unpolymerized remaining monomer in the acrylic samples. In addition, the resulted porosity from boiling the monomer led to the weakening of the test samples ${ }^{(10)}$.

These results are in disagreement with Yunus $\mathrm{N}$ et $\mathrm{al}^{(44)}$, who stated that The flexural strength of nylon denture base material thermoplastic polymers samples was significantly lower compared with two compression-molded PMMA polymers when the samples were not disinfected. In contrary, a higher value of flexural strength of nylon samples manifested after disinfection of samples using oxygen- releasing disinfectant solution.

Furthermore, Takabayashi ${ }^{(17)}$ (2010)displayed in his study that flexural strength of polyamide type materials (Valplast, Lucitone FRS and Flexite Supreme) were lower than conventional polymethyl methacrylate (Acron)

There is a reduction in flexural strength in self cure acrylic resin in comparing with heat cure acrylic resin which might be due to residual monomer ${ }^{(45)}$ in addition to plasticizing influence of absorbed water molecules during microwaving ${ }^{(46)}$.

The present study is disagreement with Ribeiro et al. ${ }^{(40)}$ who evaluated the effect of disinfection with microwave at different irradiation periods (1, $2,3,4$, or 5 minutes.) as regards the flexural strength on four self cure and one heat cure resins. They manifested that the microwave had no influence on the flexural strength of the tested materials at any irradiation periods.

In fact, the dimensional stability of a denture maintained adequate adaptation between the denture base and their casts. Clinically, it has effect on the retention of the denture as well as keeping the supporting tissues healthy. Dimensional changes can exert pressure to the alveolar bone which causing in its resorption moreover these discrepancy appears as a gap between finished dentures and their casts at the posterior palatal seal area which leads reducing retention besides stability of the dentures ${ }^{(10)}$.

The results of the present study regarding the effect of microwave disinfection with different exposure times on warpage of different study materials revealed that in case of acrylic resins materials( heat cure and self cure) the microwave disinfection caused increased in spacing. The lowest values at non disinfected samples while the highest value at 15 minutes of disinfection otherwise , there is no significant difference between them.

When comparing between the resin materials, heat cure showed more adaptation than self cure at all the time of disinfection exposure as well as in non disinfected groups but the difference is not significant .

In the case of non-disinfected groups, the decrease of the adaptation of heat cure samples to their casts resulting from the conjunction of many factors such as thermal contraction resulting from cooling the flasks, polymerization contraction, , and strain resulting from stress freeing during deflasking ${ }^{(47,48)}$.

In self cure cases the increase of the spacing resulting from incomplete polymerization of this material ${ }^{(46)}$. Dimensional changes in the disinfected heat cured samples may explained that microwave irradiation can cause raised polymerization that accompanied with contraction, Another explanation is the release of internal stresses that may be caused as a result of heat transformation of the energy of the microwave $\mathrm{e}^{(49)}$. For both explanations the longer the exposure period, the greater are the resulting changes.

In case of self cure the high temperature affects the free monomer and develops over polymerization and thereby more dimensional changes. ${ }^{(50)}$ 
These results are in agreement of Seo et al. ${ }^{(51)}$ who subjected acrylic denture bases to be disinfected by microwave at $650 \mathrm{~W}$ for $6 \mathrm{~min}$ (once per day for 7 days) they revealed that this procedure showed shrinkage of bases of the denture but the clinical finding of these returns was not considered. Additionally, they evaluated the effect microwave disinfection ( $650 \mathrm{~W} / 6 \mathrm{~min}$ ) on four types of hard liners as regards dimensional stability, they concluded that the procedure produced increased shrinkage on the specimens tested

Besides, Goncalves et al. ${ }^{(52)}$ advocated that microwave energy at $650 \mathrm{~W}$ for $6 \mathrm{~min}$ in $200 \mathrm{~mL}$ of water) showed significant decreases in the dimension of the bases of dentures

In addition, Thomas and Webb ${ }^{(53)}$ stated that significant contraction resulted after microwave radiation at 10 minutes besides, when decrease exposure time to 6 minutes the changes became smaller. Their results are in agreement of our results.

These results are in conflict with results of Burns et al. ${ }^{(54)}$ who presented that microwave radiation of samples of three several acrylic resins after 15 $\mathrm{min}$ at $650 \mathrm{~W}$ displayed on dimensional changes.

What's more, Polychronakis et al (2014) (55) concluded that irradiation of dentures in dry and wet Circumstance after 6 minutes at $650 \mathrm{~W}$ .there is no dimensional changes noticed when the disinfection occurred in wet Circumstance

On the other hand, in case of the thermoplastic resin (Breflex) The mean palatal dimensional change results showed that the thermoplastic resin was generally more significant dimensional stable in comparison to the two types of acrylic resins (heat cure and self cure) either in disinfected and non disinfected samples, noticing more higher with self cure.

These results can be explained by the fact that the higher the amount of residual monomer of the samples the higher the water absorption percentage which may result in the increase of the dimension changes ${ }^{(46)}$

Accordingly, the thermoplastic material studied in this study, which is reported to be free from monomer may have minimal water absorption in comparison with acrylic resin materials ${ }^{(56)}$

Another explanation, thermoplastic resin (Breflex) processed by the injection molding method which leads to minimizing its polymerization shrinkage and producing dentures with better accuracy than processing with the compression molding method. ${ }^{(57)}$

A study has conflicting results with the results of the present study regarding the distortion of denture base materials following microwaving, due to the utilizing of different radiation protocols( power and time). That study performed by Ali and Raghda ${ }^{(6)}$ (2011) who Estimated the influence of repeated disinfection with microwave (one, three and seven cycles each cycle pointed to $3 \mathrm{~min}$ of disinfection at 680 watt) on nylon (valplast) and heat cure denture base materials in their fitness to stone casts. Their results clarified that after the first cycle an enhancement in the fitness of heat cure and valplast denture base materials, and no more enhancement in the fitness after the repeated cycles of microwave

Pronych et al ${ }^{(56)}$ disagreement with the present results in the control groups as, they calming that there was no statistically different in the dimensional stability between a thermoplastic resin besides, two conventional polymethyl methacrylate denture base resins.

\section{CONCLUSION}

Within the limitations of this study it was concluded that :

1. Microwave disinfection had no significant effect on the colour of breflex and self cure acrylic resin at all the tested intervals $(5,10,15$ minutes $)$, 
also heatcure acrylic resin at (5,10 minutes) while, manifested colour changes at 15 minutes.

2. Microwave disinfection showed highly significant increases in the flexural strength of Breflex when comparing with heat cure samples, as well as self-cure samples

3. Microwave disinfection improves the fitness of breflex to their casts, while heat cure and self cure resin samples showed decrease in their fitness.

4. Breflex after microwave disinfection had no significant influence on its colour, significantly increase in the flexural strength, as well as dimensionally stable when compared with both heat and self cured acrylic resins.

5. Heat cure resin manifested an increase in the flexural strength as well as dimensionally stable comparing to self cure in spite of there is no significant difference between them.

\section{RECOMMENDATIONS}

- Microwave can be used safely for disinfection of all the denture base material except heat cure for 15 minutes

- Breflex is the material of choice for the construction of removable prosthodontics when using the microwave for disinfection because it has no colour changes, increasing in transverse strength as well as dimensionally stable.

- Additional laboratory studies should be done to evaluate the effect of microwave disinfection on other physical and mechanical properties of Breflex and other brands of thermoplastic resin.

- More studies should be done to evaluate repeated long-time microwave disinfection on thermoplastic resins.

- Furthermore, additional studies for breflex which can be actually utilized by the patients should be assessed.

\section{ACKNOWLEDGMENT}

This study was conducted in the Dental Biomaterials laboratory, facilities of Faculty of Dentistry, Alexandria University and Central Specialized Laboratories, Institute of Graduate Studies and Research, Alexandria University . I would like to acknowledge the members of these laboratories for their help in the perfecting and accomplishment of this work.

\section{REFERENCES}

1. Gendreau L, Loewy ZG. Epidemiology and etiology of denture stomatitis. J.Rosthodont 2011; 20:251-260

2. Neppelenbroek KH, Pavarina A C, Palomari Spolidorio D M, Sgavioli Massucato E M, Spolidorio L C , Vergan C E. Effectiveness of microwave disinfection of complete dentures on the treatment of Candida-related denture stomatitis. J Oral Rehabil 2008 ;35:836-846

3. Webb BC, Thomas CJ, Willcox MD, Harty DW, Knox KW. Candida-associated denture stomatitis. Aetiology and management: a review. Part 3. Treatment of oral candidosis. Aust Dent J. 1998;43:244-249.

4. Pires FR, Santos EB, Bonan PR, De Almeida OP, Lopes MA. Denture stomatitis and salivary Candida in Brazilian edentulous patients. J Oral Rehabil. 2002;29:1115-1119.

5. Zahra Khalili . Comparison of the Effect of Microwave Radiation in the Disinfection Complete Dentures Contaminated with Two Types of Bacteria S.aureus and P.aeruginosa (in vitro) with Mechanical and Chemical Methods of CoregaTablets . International Journal of Advanced Biotechnology and Research (IJBR) 2016;7:2017-2025

6. Ali AM, Raghdaa KJ.Evaluation and comparison of the effect of repeated microwave irradiations on some mechanical and physical properties of heat cure acrylic resin and valplast (nylon) denture base materials. J Bagh College Dentistry 2011;23:6-10

7. Brondani M A, Samim F, Feng H. A conventional microwave oven for denture cleaning: a critical review . The Gerodontology Society and John Wiley \& Sons A/S, Gerodontology 2012; 29: 6-15

8. Banting DW, Hill SA. Microwave disinfection of dentures for the treatment of oral candidiasis. Spec Care Dentist J 2001; 21:4-8.

9. Hamouda IM, Ahmed SA. Effect of microwave disinfection on mechanical properties of denture base acrylic resin. J Mech Behav Biomed Mater. 2010 Oct; 3 :480-7. 
10. Klironomos T, Katsimpali A, Polyzois G. The Effect of Microwave Disinfection on Denture Base Polymers, Liners and Teeth: A Basic Overview. Acta stomatol Croat. 2015;49: 242-253

11. Capla M, Sardi JCO, Pfeifer C, Consani RLX. Effect of Different Simulated Microwave Disinfection Cycles on Hardness, Roughness and Gloss of Acrylic Resins. Int J Dentistry Oral Sci. 2017;4: 575-580.

12. DixonDL, BreedingLC, FalerTA.microwave disinfections of denture base materials colonized with Candida albicans. Jprosthet Dent 1999; 81:207-214

13. Silva MM, Vergani CE, GiamPaolo ET, et al: Effectiveness of microwave irradiation on the disinfection of complete dentures.Int J prosthodont .2006; $19: 288-293$

14. Vergani C E, Ribeiro D G, Dovigo L N, Sanitá P Vand, Pavarina A C Microwave Assisted Disinfection Method in Dentistry. United Kingdom London, INTECH Open Access Limited. 2011;pp: 3978

15. Leon BL, Del Bel Cury AA, Rodrigues GarciaRC . water sorption solubility and tensile bond strength of reselient denture lining materials polymerized by diferent methods after thermal cycling J Prosthet Dent. 2005 Mar;93: 282-287

16. Abhay P N , Karishma S. Comparative Evaluation of Impact and Flexural Strength of Four Commercially Available Flexible Denture Base Materials: An In Vitro Study. J Indian Prosthodont Soc . 2013 ;13:499-508

17. Takabayashi Y. Characteristics of denture thermoplastic resins for non-metal clasp dentures. Dent Mater J .2010;29:353-361

18. Singh K, Aeran H, Kumar N, Gupta N. Flexible thermoplastic denture base materials for aesthetical removable partial denture framework. J Clin Diagn Res 2013; 7 : 2372-2373.

19. Salama F, Al-Rashed S, Al-khunaini N, Abou-Obaid A, Elsharawy M. Effect of Denture Cleansers on Color Stability of Different Acrylic Resin Materials .IOSR 2017 ; 16: 70

20. American Dental Association Specification No.12.Guide to dental materials and devices. $10^{\text {th }}$ ed. Chicago;1999. p.32

21. Hamad TI, Fatihallah AA, AbdulsahibAJ.The effect of different investment materials on dimensional accuracy and surface roughness of thermsens maxillary complete dentures. J Baghdad Coll Dent 2015;27:1-7
22. Glazier S, Firtell DN, Harman LL. Posterior peripheral seal distortion related to height of the maxillary ridge. J Prosthet Dent 1980; 43: 508-510

23. Al-Saraj A N, Kazanji M N, Abdul-Rahman GY .Effect of Microwave Disinfection on Transverse Strength and Hardness of Acrylic Resin Denture Base Materials. Al Rafidain Dent J .2011; 11: 284 - 291

24. CIE (Commission International de l'Eclairage) Colorimetry technical report. CIE Publication No.15. 2. Vienna, Austria: Bureau Central de la CIE; 1986.11.

25. Chen H, Huang J, Dong X. A systematic review of visual and instrumental measurements for tooth shade matching. Quintessence Int. 2012; 43: 649-659.13.

26. Consani R1,Iwasaki RY,Mesquita MF,Mendes WB,Consani S.Effect of repeated simulated disinfections by microwave energy on the complete denture base adaptation.Open Dent J2008;2:61-6

27. Paravina RD, Powers JM. Esthetic Color Training in Dentistry, 1st edn. St. Louis: Mosby, 2004: 84-87.

28. Waliszewski M. Restoring dentate appearance: a literature review for modern complete denture esthetics. J Prosthet Dent 2005; 93: 386-394.

29. Hong G, Murata H, Li Y, Sadamori S, Hamada T. Influence of denture cleansers on the color stability of three types of denture base acrylic resin. J Prosthet Dent. 2009;101(3):205-13.

30. Goiato M C., dos Santos D M., Baptista G T., Moreno A 1, Andreotti A M., Bannwart L C. , Dekon S F. Effect of thermal cycling and disinfection on colour stability of denture base acrylic resin. Gerodontology 2013; 30 276-282

31. Huggett R, Brooks SC, Campbell AM et al. Evaluation of analytical techniques for measurement of denture-base acrylic resin glass-transition temperature. Dent Mater 1990; 6: 17-19.

32. Pow EH, Chow TW, Clark RK. Linear dimensional change of heat-cured acrylic resin complete dentures after reline and rebase. J Prosthet Dent 1998; 80: 238-245.

33. Polychronakis N,Polyzois G,Lagouvardos P,Andreopoulos A, Ngo H C.Longterm microwaving of denture base materials: effects on dimensional, color and translucency stability. J Appl Oral Sci. 2018 Jun 18;26

34. Polychronakis N C, Polyzois G L, Lagouvardos P E, Papadopoulos $\mathrm{T}$ D. Effects of cleansing methods on 3-D surface roughness, gloss and color of a polyamide denture base material.Acta Odontol Scand. 2015 Jul;73:353-63

35. 18. Nimeroff I. Colorimetry. Natl Bureau Stand Monogr 1968; 104: 4-32. 
36. Goiato M C., Dos Santos D M., Baptista G T., Moreno A, Andreotti AM., Bannwart L C. , Dekon S F. Effect of thermal cycling and disinfection on colour stability of denture base acrylic resin Gerodontology 2013; 30 (4):276-282

37. Konchada J, Karthigeyan S, Asharaf Ali S, Venkateshwaran R, Amirisetty R, Dani A. Effect of simulated microwave disinfection on the mechanical properties of three different types of denture base resins. J Clin Diagn Res. 2013;7:3051-3053.

38. Oliveira MEG, Pavarina AC, Neppelenbroek KH et al. Effect of different exposure times of microwave irradiation on the disinfection of a hard chairside reline resin. $\mathrm{J}$ Prosthodont 2008; 17: 312-317

39. Fleck G, Ferneda F, Ferreira da Silva DF et al. Effect of two microwave disinfection protocols on adaptation of poly (methyl methacrylate) denture bases. Minerva Stomatol 2007; 56: 121-127

40. Ribeiro DG, Pavarina AC, Machado AL, Giampaolo ET, Vergani CE. Flexural strength and hardness of reline and denture base acrylic resins after different exposure times of microwave disinfection. Quintessence Int. 2008 Nov;39:833-840

41. Consani RL, Vieira EB, Mesquita MF. Effect of microwave disinfection on physical and mechanical properties of acrylic resins. Braz Dent J. 2008;19:348-53

42. Soygun K, Bolayir G, Boztug A. Mechanical and thermal properties of polyamide versus reinforced PMMA denture base materials. J Adv Prosthodont 2013; 5: 153-160.

43. Ucar Y, Akova T, Aysan I. Mechanical properties of polyamide versus different PMMA denture base materials. J Prosthodont 2012; 21: 173-176.

44. Yunus N, Rashid A. A., Azmi L. L. . Abu-Hassan M. I Some flexural properties of a nylon denture base polymer Journal of Oral Rehabilitation 2005 ;32: 65-7.

45. Dogan A, Bek B, Cevik NN,Usanmaz A. The effect of preparation conditions of acrylic denture base materials on the level of residual monomer, mechanical properties and water absorption. J Dent. 1995 ;23:313-318.

46. Takahashi Y, Chai J, Kawagucci M. Effect of water sorption on the resistance to plastic deformation of a denture base material relined with four different denture reline materials. Int J Prosthodont. 1998 ; 11:49-54.
47. Consani R L, Domitti S S , Mesquita M F, Consani S.Effect of Packing Types on the Dimensional Accuracy of Denture Base Resin Cured by the Conventional Cycle in Relation to Post-pressing Times Braz Dent J .2004; 15: 63-67

48. Savabi G, Savabi O, Dastgheib B, Nejatidanesh F. Effect of the processing cycle on dimensional changes of heatpolymerized denture base resins. Dent Res J(Asfahan) . 2015 ;12:301-306.

49. Keenan PL, Radford DR, Clark RK. Dimensional change in complete dentures fabricated by injection molding and microwave processing. J Prosthet Dent. 2003; 89:37-44.

50. Urban VM, Machado AL, Oliveira RV, Vergani CE, Pavarina AC, Cass QB. Residual monomer of reline acrylic resins. Effect of water bath and microwave postpolymerization treatments. Dent Mater. 2007 ;23:363-368

51. Seo RS, Vergani CE, Pavarina AC, Compagnoni MA, Machado AL. Influence of microwave disinfection on the dimensional stability of intact and relined acrylic resin denture bases. J Prosthet Dent. 2007 ;98(3):216-223.

52. Goncalves AR, Machado AL, Giampaolo ET, Pavarina AC, Vergani CE. Linear dimensional changes of denture base and hard chairside reline resins after disinfection. J Appl Polym Sci. 2006;102:1821-1826.

53. ThomasCJ,Webb BC. Microwaving of acrylic resin dentures. Eur J Prosthodont Restor Dent 1995; 3: 179-182

54. Burns DR, Kazanoglu A, Moon PC, Gunsolley JC. Dimensional stability of acrylic resin materials after microwave sterilization. Int J Prosthodont. 1990 ;3:489-493

55. Polychronakis N, Yannikakis S, Zissis A. The effect of repeated microwaving disinfection on the dimensional stability of acrylic dentures. Acta Stomatol Croat. $2014 ; 48$ : 279-284

56. Pronych G. J., Sutow E. J. ,Sykor O. Dimensional stability and dehydration of a thermoplastic polycarbonate-based and two PMMA-based denture resins. J Oral Rehabi 1. 2003 30; 1157-1161

57. Abhay PN, Karishma S. Comparative Evaluation of Impact and Flexural Strength of Four Commercially Available Flexible Denture Base Materials: An In Vitro Study. J Indian Prosthodont Soc 2013;13:499-508 